Journal of Social Sciences 6 (3): 498-507, 2010

ISSN 1549-3652

(C) 2010 Science Publications

\title{
Seeking an Alternative Modality to the Management of Nigeria's Fertilizer Subsidy Scheme-An Empirical Approach to the Case Study of Ondo State (1976-1996)
}

\author{
${ }^{1}$ Victor O. Asekunowo, ${ }^{1}$ Grace T. Olutunla and ${ }^{2}$ Adebiyi G. Daramola \\ ${ }^{1}$ Department of General Studies, Federal University of Technology, \\ P.M.B. 704, Akure, Ondo State, Nigeria \\ ${ }^{2}$ Department of Agricultural Economics, Federal University of Technology, \\ P.M.B. 704, Akure, Ondo State, Nigeria
}

\begin{abstract}
Problem statement: The objective of Nigeria's fertilizer subsidy scheme was to make inorganic fertilizers readily available to farmers at affordable prices in order to boost food production in the country. Shortly into the scheme, farmers complained that fertilizers were not received at the time of need and in sufficient quantities. Approach: Using Ondo State, Nigeria as a case study, to determine; inter alia, if the farmers' complaints were founded and if so, to design alternative ways of administering the scheme such that the lofty goals for which it was established could be realized. Methodology: Primary data were collected from 596 farmers randomly selected from the state. Secondary data were collected from purposively selected NAFCON, AISC, ADP, FPDD (now FFD) and a published book source. The primary data were analyzed with the use of descriptive statistics such as percentages and means. The secondary data were analyzed with the use of OLS and TLS regression methods. Results: The descriptive analyses showed that farmers in Ondo State did not receive their fertilizer supplies in sufficient quantities and at the time of need, despite the fact that supply surpassed adoption (demand) for most years of the study period. The inferential analyses showed that a subsidy introduced into NAFCON and other producing firms' production processes would engender increased output and induce fertilizer prices to fall in Ondo State. Conclusion: These results showed that farmers in Ondo State did not receive their fertilizer supplies at the time of need and in sufficient quantities due to leakages and diversion of the substance from the vast bureaucratic distribution channels. As an alternative, if subsidy was administered through the producing firms' production processes, output of fertilizers would have increased making the market supply curve of fertilizers to shift to the right. This would have also caused the price of fertilizer to fall in the state.
\end{abstract}

Key words: Fertilizer subsidy, retention price, fertilizer industry, NAFCON, quantity of fertilizers

\section{INTRODUCTION}

Consequent upon a sharp decline in the rate of growth of food and fiber production especially in the late 1960 s and early 1970s, successive Federal Governments in Nigeria, since the early 1970s, have instituted some agricultural programs with a view to solving this problem. The Agricultural Development Project (ADP) was established in 1975 as an input distribution and delivery system, which ensured that farmers did not have to travel more than $5-15 \mathrm{~km}$ to purchase needed farm inputs. Because of the importance of fertilizer amongst other inputs, it has occupied a prominent place in the national agricultural policy. Thus, purchases of inorganic fertilizers such as
Compound Fertilizer (NPK), Urea Fertilizer and Single Super phosphate Fertilizer (SSP) by the Federal Government from domestic fertilizer producers were used to supplement foreign procurement and distributed to farmers all over the Federation at heavily subsidized rates.

However, no sooner had all the above been done than the farmers started complaining persistently that not enough of the subsidized commodity was received by them during the crucial planting periods. Also, the consumers' situation has not improved because the proportion of their disposable incomes expended on foods has continued to increase over the years. It is therefore the objectives of this study to evaluate the fertilizer subsidy program and identify the 


\section{J. Social Sci., 6 (3): 498-507, 2010}

inefficiencies in the administration of the program in Ondo State, Nigeria from 1976-1996, to analyze the supply and demand patterns of fertilizers in Ondo State during the study period and to design market intervention aimed at removing likely inefficiencies in the present administration of the scheme. The study concludes by making recommendations.

Literature review and theoretical framework: Subsidy as a policy instrument has been used by governments worldwide to pursue different sectoral objectives. This review therefore would not be limited to subsidy as it affects production in the fertilizer industry alone but would also review production subsidies in other areas such as industrial subsidy and cotton production subsidy.

In India for instance, the government instituted a policy of input price subsidization in the fertilizer industry and then removed it during the era of deregulation and liberalization. Schumacher and Sathaye (1999) investigated the relationship between input usage, productivity and growth in the value of output in India's fertilizer industry during the subsidization years (1973-1991) and the liberalization years (1991-1993). During the subsidization years, the difference between the retention price (mainly based on production cost) and the ceiling on the prices of fertilizers sold to the farmers was the level of input subsidization to the fertilizer industry. The study used cross state and national time series data. Kendrick and translog cost function (variants of production functions) approach were adopted. Also adopted was Solow approach which assumed a neo-classical Cobb-Douglas specification of production function with constant returns to scale, perfect competition in the market and factors being rewarded their marginal products.

Specifying the growth value of output as the dependent variable and labor, capital, energy and material inputs as the independent variables, Schumacher and Sathaye (1999) submitted that on the average, total input usage, total productivity and value of output growth annually were 9.81, 3.60 and $13.41 \%$ respectively during the subsidization years. They also found that input usage, total productivity and value of output annually were $-2.18,-8.44$ and $-10.62 \%$ respectively during the liberalization years. The findings of the study concerning the subsidizing years seemed to confirm the submission of Lingard (2002) that subsidies will increase the use of variable production inputs. Disagreeing with these submissions, Zalla and Saad (1998) in their study on fertilizer production and marketing in Egypt found that following the elimination of subsidies (in 1992), the domestic production of nitrogenous fertilizers increased by $3.6 \%$ per year, while the production of phosphate grew by just over $1 \%$.

When discussing the issue of fertilizer production subsidy around the world, two eras stand out: The era of monopoly in production, purchase and distribution of fertilizers in the 1970s and the very early 1980s and the era of deregulation and liberalization which started in the mid 1980s. Considering the era of monopoly, subsidization to producers of fertilizers can be of two types: direct payment based on the per unit of fertilizers produced or input price support. The latter has been widely adopted by governments albeit with varying degree of modifications.

Subsidies to fertilizer producers have been used to stimulate domestic fertilizer production to ensure adequate and timely supply, save foreign exchange and promote economic development especially in countries with high energy cost or dependence on imported raw materials. Nitrogen production has been subsidized in India, Bangladesh, Indonesia, Mexico and Egypt whereas phosphate production has been subsidized in India, Indonesia, China, Morocco and Pakistan (IFDC, 2003b). For different studies on Phillipines, India and Egypt (David and Balisacan, 1981; Ranade and Kapur, 2001). In these countries, the production subsidies work thus: the production costs (which usually consists of the cost of feedstock, energy) are first calculated. This is referred to as the retention price. The ceiling price at which fertilizers are sold to the farmers is then subtracted from the retention price. The difference is the per unit input price subsidy paid to the producers in the fertilizer industry.

The financing of this level of subsidization usually requires a huge budgetary outlay. For the developed world, financing subsidy schemes does not pose many problems. For instance in 1998, net transfers to agriculture in OECD countries amounted to $\$ 362$ billion, approximately three quarters of which were in forms of producer supports (Robin et al., 2003). But for many developing countries with many developmental needs, such outlays had adverse impact on national, state and local government budgets. For example, in Nigeria, between 1991 and 1992, the fertilizer subsidy cost, as a percentage of the national budget, ranged from $16.8 \%$ in 1991 to a high of $42.7 \%$ in 1992 (IFDC, 2005; Nagy and Edun, 2002). Most of these developing nations rely on the contributions of donor nations to finance their agricultural outlays. So at the prodding of the donors, these countries since the mid 1980s, sought to deregulate and liberalize their fertilizer sectors. Existing literature on the best framework to adopt for an efficient fertilizer procurement and distribution tend 


\section{J. Social Sci., 6 (3): 498-507, 2010}

to emphasize the need to reduce transaction costs (supply side approach) involved in fertilizer distribution (IFDC, 2003a; 2003b; Nagy and Edun, 2002; Debra, 2001). Models in these studies used simple linear supply and demand equations in which supply and demand were the endogenous variables and price was the only exogenous variable. The studies suggested that an embrace of a supply-side, market friendly fertilizer distribution framework would induce the Shifting of the Supply Curve to the Right (SSCR) so that at equilibrium, the unit price of fertilizer would fall and the quantity of fertilizer supplied would rise.

The factors that engender a market friendly fertilizer distribution system and hence a reduction in the transaction cost of fertilizer distribution according to the studies are: the creation of a conducive macro policy, declaration and adherence to consistent input marketing policy, building human capital for market development, improving access to finance, developing and implementing regulatory frameworks, promoting market transparency through market information systems, promoting technology transfer activities and strengthening research capacity for promoting the private seed industry.

Gadzey et al. (2005) in trying to examine the effectiveness of industrial subsidies on manufacturing output in state of Alabama, USA used panel data across 20 counties in the state from 1970-1999 in the pooled regression. The independent variables were county subsidies, population density and the usage bill. The dependent variable was industrial output. The empirical results showed that subsidies have a positive effect on county output. Specifically, the coefficient of the subsidies variable indicated an impact of $\$ 6.61$ per $\$ 1000$ of grant.

Studies have also been carried out that showed, inter alia, the effect of subsidy on output or production. In the fall of 2002 Brazil brought a complaint about US cotton subsidies to the dispute settlement panel of the W T O. Brazil claimed that US support for cotton granted in the period 1999-2002 exceeded that level allowed under WTO agreements and therefore caused the world price of cotton to fall. Sumner (2003) used econometric model adapted from and largely based on the key supply and demand elasticity's from the wellknown and respected Food and Agricultural Policy Research Institute (FAPRI) to examine by simulation the export and world price effects of removing the six major US subsidies supporting US production and export of Upland cotton.

The simulation model used made some assumptions on the elasticity's on the variables. These variables are the expected price yield, marketing loan benefits yield, production flexibility contract payment, direct payments, market loss assistance payments, counter-cyclical payments, crop insurance subsidy and cost per acre were specified in the supply equation (proxied by expected revenue because it is expected that subsidies that increase the expected net revenue per acre planted would naturally increase the quantity supplied). The variables that entered into the demand equation are price minus domestic step 2 payment, price minus export step-2 payment and export credit. Based on the assumption made on the supply and demand elasticity's, the baseline figures were derived for US cotton production, US exports, US mill use of cotton, US average price and world price when the subsidies were assumed to be in place. A policy scenario which assumed that the subsidies were removed was thereafter simulated.

Sumner (2003) submitted that removing the subsidies simultaneously would cause a fall in US exports on the average by almost $43 \%$, would cause the US market price on the average to rise by $15.2 \%$ and would cause the world price of Upland cotton to rise on the average by about $11.6 \%$.

Poonyth et al. (2004) assuming different elasticity's in the computation of the baseline figures, used essentially the same variables in their supply and demand equations. The baseline figures derived were subjected to the Agricultural Trade Policy Simulation Model (ATPSM). They simulated a policy scenario that assumed the removal of cotton subsidies would reduce world price cotton between 3.1 and $4.8 \%$. They also estimated that cotton output in non-subsidizing countries would reduce by $2 \%$. Output was also estimated to decrease by $15 \%$ in the United States and by $32 \%$ in the EU Countries.

Shepherd (2005) used Vector Auto Regression (VAR) model in which the following variables were modeled as the endogenous variables: nominal world price of cotton, total world consumption of cotton, change in the level of total world stocks of cotton. The model then specified the lagged values of the preceding variables and subsidies as the exogenous variables. Shepherd (2005) found that the world production of cotton responded to a subsidy shock. He however found that the response of price to subsidy shock was not as robust as reported in the studies of Goreux (2004); Sumner (2003) and Poonyth et al. (2004).

\section{MATERIALS AND METHODS}

The study area is Ondo State, Nigeria. Ondo state consists of eighteen Local Government Areas. Ilaje and Eseodo Local Government Areas were excluded from 
the study because they are in the main riverine areas where food crop farming is not known to be largely practiced; therefore, fertilizers are not adopted in these areas. The remaining sixteen Local Government Areas constituted the study area. However, owing to financial constraints, the sample was chosen from twelve Local Government Areas. These Local Government Areas were divided into three different climatic zones into which state could be divided i.e. the Southern zone, the Central zone and the Northern zone. The Southern zone comprised the following Local Government AreasIrele, Okitipupa, Odigbo and Ondo West Local Government Areas; the Central zone comprised the following Local Government Areas-Akure-South, Akure-North, Idanre and Ile-Oluji/Okeigbo Local Government Areas and the Northern zone comprised the following Local Government Areas-Akoko Northwest, Akoko Southwest, Akoko Northeast and Akoko Southeast.

The target groups were from these Local Government Areas. The target groups were the farmers who have adopted fertilizers during the study period, governmental agencies within the state such as Agricultural Development Project (ADP), Agricultural Input Supply Company (AISC), governmental agencies outside the state such as the National Fertilizer Company of Nigeria (NAFCON which stopped production of fertilizers in 1999 and is now acquired by NOTORE (a chemical company) under the Nigerian Government's policy of privatization of State Owned Enterprises. NOTORE is yet to start production of fertilizers) and the Fertilizer Procurement and Distribution Department (FPDD) now the Federal Fertilizer Department (FFD). All these agencies have valuable information which is pertinent to the study in their archives.

Samples were drawn from the twelve Local Government Areas in the three zones. Primary data were collected with the use of questionnaires administered on the target groups. A total number of eight hundred and sixteen questionnaires were sent out for administration on the farmers in the twelve Local Government Areas i.e., sixty-eight questionnaires were sent to each Local Government Area. Farmers who have adopted fertilizers during the study period were randomly selected and questions concerning whether they received their fertilizers in sufficient quantities and at the time of need, fertilizer usage and point of collection of fertilizers were asked by Enumerators. Purposive sampling was utilized to collect secondary data from the governmental agencies by the researchers. Data on the quantities of fertilizers received in Ondo state were collected from AISC and ADP. Data on the quantities of fertilizers sent to Ondo state were collected from FPDD now FDD. Data on the income of farmers and the quantities of fertilizers consumed in Ondo state were collected from ADP. Data on the quantities of fertilizers produced and the prices of inputs used in the production process were collected from NAFCON.

Secondary data on the prices of fertilizers were collected from the Report of the Fertilizer Inventorization Study Team. Indexes were constructed on NAFCON's fertilizer production; NAFCON's input (equipment, replacement parts, labor, materials) usage without subsidy, NAFCON's input usage with subsidy. The indexes were expressed in quarterly figures. The prices of fertilizers and the prices of the inputs in the base year i.e., 1976 were used as weights. According to Shao (1976) "when the weight is the number of the base year (that is, $\mathrm{w}=\mathrm{q}_{\mathrm{o}}$ or $\mathrm{w}=\mathrm{p}_{\mathrm{o}}$ ), the index is called Laspeyres index".

The data collected on the farmers from the questionnaires were descriptively analyzed. The indexes constructed on NAFCON's production of fertilizers, NAFCON's input usage with or without subsidy were fitted into Ordinary Least Squares (OLS) regression models and econometrically analyzed. The data collected on the quantities of fertilizers produced without subsidy and supplied to Ondo state by NAFCON, the quantities of fertilizers produced with subsidy and supplied to Ondo state by NAFCON, the prices and quantity demanded of fertilizers in Ondo state were fitted into Two-Stage Least Squares (TLS) regression models and econometrically analyzed:

\section{Model (A):}

$$
\log \frac{\sum \mathrm{Q}_{\mathrm{n}} \mathrm{P}_{\mathrm{o}}}{\sum \mathrm{Q}_{\mathrm{o}} \mathrm{P}_{\mathrm{o}}}=\partial+\theta \log \left[\frac{\sum \mathrm{q}_{\mathrm{n}} \mathrm{p}_{\mathrm{o}}}{\sum \mathrm{q}_{\mathrm{o}} \mathrm{p}_{\mathrm{o}}}\right]+\mathrm{U}_{\mathrm{i}}
$$

Where:

$$
\begin{aligned}
& \log \frac{\sum \mathrm{Q}_{\mathrm{n}} \mathrm{P}_{\mathrm{o}}}{\sum \mathrm{Q}_{\mathrm{o}} \mathrm{P}_{\mathrm{o}}}=\text { Weighted quantity index of fertilizers } \\
& \text { produced by NAFCON } \\
& \partial \quad=\text { Intercept term } \\
& \theta=\text { Estimator of weighted index of input }
\end{aligned}
$$


Model (B):

$$
\begin{aligned}
& \log \frac{\sum \mathrm{Q}_{\mathrm{n}} \mathrm{P}_{\mathrm{o}}}{\sum \mathrm{Q}_{\mathrm{o}} \mathrm{P}_{\mathrm{o}}}=\partial+\theta \log \left[\frac{\sum \mathrm{q}_{\mathrm{n}} \mathrm{P}_{\mathrm{o}}(1+\mathrm{s})}{\sum \mathrm{q}_{\mathrm{o}} \mathrm{p}_{\mathrm{o}}}\right]+\mathrm{U}_{\mathrm{i}} \\
& \Rightarrow \log \frac{\sum \mathrm{Q}_{\mathrm{n}} \mathrm{P}_{\mathrm{o}}}{\sum \mathrm{Q}_{\mathrm{o}} \mathrm{P}_{\mathrm{o}}}=\partial+\theta \log \left[\frac{\sum \mathrm{q}_{\mathrm{n}} \mathrm{P}_{\mathrm{o}}}{\sum \mathrm{q}_{\mathrm{o}} \mathrm{P}_{\mathrm{o}}}\right]+\lambda \log \left[\frac{\sum \mathrm{N}_{\mathrm{n}} \mathrm{P}_{\mathrm{o}}}{\sum \mathrm{q}_{\mathrm{o}} \mathrm{P}_{\mathrm{o}}}\right]+\mathrm{U}_{\mathrm{i}}
\end{aligned}
$$

Where:

$$
\begin{aligned}
\log \frac{\sum \mathrm{Q}_{\mathrm{n}} \mathrm{P}_{\mathrm{o}}}{\sum \mathrm{Q}_{\mathrm{o}} \mathrm{P}_{\mathrm{o}}}= & \text { Weighted index of fertilizers produced } \\
& \text { by NAFCON } \\
\theta \quad & \text { Intercept term } \\
\theta \quad & \text { Estimator or coefficient of weighted } \\
& \text { inputs without subsidy }
\end{aligned}
$$$$
\log \frac{\sum \mathrm{q}_{\mathrm{n}} \mathrm{P}_{\mathrm{o}}(1+\mathrm{s})}{\sum \mathrm{q}_{\mathrm{o}} \mathrm{p}_{\mathrm{o}}} \Rightarrow
$$

$\log \frac{\sum \mathrm{q}_{\mathrm{n}} \mathrm{P}_{\mathrm{o}}}{\sum \mathrm{q}_{\mathrm{o}} \mathrm{p}_{\mathrm{o}}}=$ Index of input usage without subsidy

$\log \frac{\sum_{\mathrm{s}} \mathrm{q}_{\mathrm{n}} \mathrm{P}_{\mathrm{o}}}{\sum \mathrm{q}_{\mathrm{o}} \mathrm{p}_{\mathrm{o}}}=$ Index of input usage induced by subsidy:

\section{$\operatorname{Model}\left(\mathbf{C}_{\mathrm{i}}\right)$ :}

$\mathrm{Q}_{\mathrm{fso}}=\beta_{\mathrm{o}}+\beta_{1} \mathrm{P}_{\mathrm{m}}+\mathrm{U}_{1 \mathrm{t}}$

$\mathrm{Q}_{\mathrm{fdo}}=\alpha_{\mathrm{o}}+\alpha_{1} \mathrm{P}_{\mathrm{m}}+\mathrm{U}_{2 \mathrm{t}}$

$\left(\beta_{0}, \beta_{1}, \alpha_{0}>0\right.$ and $\left.\alpha_{1}<0\right)$

Where:

$\mathrm{Q}_{\mathrm{fso}}=$ Quantity of fertilizers shipped to Ondo state and assumed produced without subsidy

$\beta_{\mathrm{o}}=$ Intercept term of supply equation

$\beta_{1}=$ Estimator

$\mathrm{P}_{\mathrm{m}}=$ Price of fertilizer in supply and demand equations

$\mathrm{U}_{1 \mathrm{t}}=$ Stochastic disturbance term

$\mathrm{Q}_{\mathrm{fdo}}=$ Quantity of fertilizers used (adopted) by farmers in Ondo State

$\alpha_{0}=$ Intercept term of demand equation

$\alpha_{1}=$ Estimator of average price of fertilizers in demand equation

$\mathrm{U}_{2 \mathrm{t}}=$ Stochastic disturbance term

The equations in model $\left(\mathrm{C}_{\mathrm{i}}\right)$ are dependent in that any disturbance caused by $\mathrm{U}_{1 \mathrm{t}}$ such as strikes, tariffs, exchange rate fluctuations would affect $\mathrm{P}_{\mathrm{m}}$ in both equations. Likewise, a disturbance caused by $\mathrm{U}_{2 \mathrm{t}}$ like increase in income of farmers, increase in hectares of land cultivated by farmers would affect $\mathrm{P}_{\mathrm{m}}$ in both equations. Consequently, $\mathrm{P}_{\mathrm{m}}$ should be regarded as an endogenous variable just like $\mathrm{Q}_{\mathrm{fso}}$ and $\mathrm{Q}_{\mathrm{fdo}}$ in this system of structural equations. According to Gujarati (1987), "a regression of $\mathrm{Q}$ on $\mathrm{P}_{\mathrm{m}}$ would violate an important assumption of the classical linear regression model, namely, the assumption of no correlation between the explanatory variable (s) and the disturbance term". In his view, if this is ignored, "the least-squares estimators are not only biased but also inconsistent; that is, as the sample size increases indefinitely, estimators do not converge to their true (population) values (Gujarati, 1987).

As a way out of this, two new variables, $\mathrm{P}_{\mathrm{m}-1}$ (lagged one value of the average price of fertilizers) and I (the average income of farmers) were introduced into the structural linear supply and demand functions respectively. Model $\left(\mathrm{C}_{\mathrm{i}}\right)$ then becomes:

\section{Model $\left(\mathbf{C}_{\mathrm{ii}}\right)$ :}

$$
\begin{aligned}
& \mathrm{Q}_{\mathrm{fso}}=\beta_{\mathrm{o}}+\beta_{1} \mathrm{P}_{\mathrm{m}}+\beta_{2} \mathrm{P}_{\mathrm{m}-1}+\mathrm{U}_{\mathrm{tt}} \\
& \mathrm{Q}_{\mathrm{fdo}}=\alpha_{\mathrm{o}}+\alpha_{1} \mathrm{P}_{\mathrm{m}}+\alpha_{2} \mathrm{I}+\mathrm{U}_{2 \mathrm{t}}
\end{aligned}
$$

From this new system of equations, reduced form equations could be derived in which $Q$ and $P_{m}$ (endogenous) variables are expressed in terms of predetermined (exogenous) variables I and $\mathrm{P}_{\mathrm{m}-1}$ :

$$
\begin{aligned}
& \mathrm{P}_{\mathrm{m}}=\prod_{0}+\prod_{1} \mathrm{P}_{\mathrm{m}-1}+\prod_{2} \mathrm{I}+\mathrm{V}_{\mathrm{t}} \\
& \mathrm{Q}=\prod_{3}+\prod_{4} \mathrm{P}_{\mathrm{m}-1}+\prod_{5} \mathrm{I}+\mathrm{W}_{\mathrm{t}}
\end{aligned}
$$

Where:

$$
\begin{aligned}
& \Pi_{0}=\frac{\alpha_{0}-\beta_{0}}{\beta_{1}-\alpha_{1}} \\
& \Pi_{1}=\frac{\alpha_{2}}{\beta_{1}-\alpha_{1}} \\
& \Pi_{2}=\frac{-\beta_{2}}{\beta_{1}-\alpha_{1}} \\
& \mathrm{~V}_{\mathrm{t}}=\frac{\mathrm{U}_{2 \mathrm{t}}-\mathrm{U}_{1 \mathrm{t}}}{\beta_{1}-\alpha_{1}} \\
& \Pi_{3}=\frac{\alpha_{0} \beta_{1}-\alpha_{1} \beta_{0}}{\beta_{1}-\alpha_{1}} \\
& \prod_{4}=\frac{\alpha_{1} \alpha_{2}}{\beta_{1}-\alpha_{1}}
\end{aligned}
$$


$\Pi_{5}=\frac{-\alpha_{1} \beta_{2}}{\beta_{1}-\alpha_{1}}$

$\mathrm{W}_{\mathrm{t}}=\frac{\alpha_{1} \mathrm{U}_{2 \mathrm{t}}-\alpha_{\mathrm{t}} \mathrm{U}_{1 \mathrm{t}}}{\beta_{1}-\alpha_{1}}$

From the six reduced-form equations $\left(\Pi_{0}, \Pi_{1}, \Pi_{2}, \Pi_{3}, \Pi_{4}\right.$ and $\left.\Pi_{5}\right)$ six structural coefficients or estimators $\left(\beta_{0}, \beta_{1}, \beta_{2}, \alpha_{0}, \alpha_{1}\right.$ and $\left.\alpha_{2}\right)$ can be indirectly estimated:

$\operatorname{Model}\left(\mathbf{D}_{\mathbf{i}}\right)$ :

$\mathrm{Q}_{\mathrm{fss}_{\mathrm{o}}}=\mathrm{s} \beta_{0}+\beta_{1} \mathrm{P}_{\mathrm{m}}+\mathrm{U}_{\mathrm{tt}}$

$\mathrm{Q}_{\mathrm{fd}_{\mathrm{o}}}=\alpha_{0}+\alpha_{1} \mathrm{P}_{\mathrm{m}}+\mathrm{U}_{2 \mathrm{t}}$

Note that factor $\mathrm{s}$ is attached to the intercept term which is expected to cause the supply curve $\left(\mathrm{Q}_{\mathrm{fsso}}\right)$ to shift to the right to intersect a stationary demand curve $\left(\mathrm{Q}_{\mathrm{fdo}}\right)$. Assumption here is that the fertilizers shipped to Ondo State are produced with a subsidy.

Again, because the system of equations in $\left(D_{i}\right)$ are dependent which may lead to biased and inconsistent estimators, the lagged value of average price of fertilizers $\left(\mathrm{P}_{\mathrm{m}-1}\right)$ and average income of farmers (I) are introduced. Model $\left(\mathrm{D}_{\mathrm{i}}\right)$ becomes:

$\operatorname{Model}\left(\mathbf{D}_{\mathrm{ii}}\right)$ :

$$
\begin{aligned}
& \mathrm{Q}_{\mathrm{fsso}}=\mathrm{s} \beta_{0}+\beta_{1} \mathrm{P}_{\mathrm{m}}+\beta_{2} \mathrm{P}_{\mathrm{m}-1}+\mathrm{U}_{1 \mathrm{t}} \\
& \mathrm{Q}_{\mathrm{fd}_{\mathrm{o}}}=\alpha_{0}+\alpha_{1} \mathrm{P}_{\mathrm{m}}+\mathrm{a}_{2} \mathrm{I}+\mathrm{U}_{2 \mathrm{t}}
\end{aligned}
$$

From this, reduced form equations are derived in which $\mathrm{Q}$ and $\mathrm{P}_{\mathrm{m}}$ (endogenous) variables are expressed in terms of pre-determined (exogenous) variables I and $\mathrm{P}_{\mathrm{m}-1}$ :

$$
\begin{aligned}
& \mathrm{P}_{\mathrm{m}}=\prod_{0}+\prod_{1} \mathrm{P}_{\mathrm{m}-1}+\prod_{2} \mathrm{I}+\mathrm{V}_{\mathrm{t}} \\
& \mathrm{Q}=\prod_{3}+\prod_{4} \mathrm{P}_{\mathrm{m}-1}+\prod_{5} \mathrm{I}+\mathrm{W}_{\mathrm{t}}
\end{aligned}
$$

Where:

$$
\begin{aligned}
& \prod_{0}=\frac{\alpha_{0}-\beta_{0}}{\beta_{1}-\alpha_{1}} \\
& \prod_{1}=\frac{\alpha_{2}}{\beta_{1}-\alpha_{1}}
\end{aligned}
$$

$$
\begin{aligned}
& \Pi_{2}=\frac{-\beta_{2}}{\beta_{1}-\alpha_{1}} \\
& \mathrm{~V}_{\mathrm{t}}=\frac{\mathrm{U}_{2 \mathrm{t}}-\mathrm{U}_{1 \mathrm{t}}}{\beta_{1}-\alpha_{1}}
\end{aligned}
$$

$\Pi_{3}=\frac{\alpha_{0} \beta_{1}-\alpha_{1} \beta_{0}}{\beta_{1}-\alpha_{1}}$

$\Pi_{4}=\frac{\alpha_{1} \alpha_{2}}{\beta_{1}-\alpha_{1}}$

$\Pi_{5}=\frac{-\alpha_{1} \beta_{2}}{\beta_{1}-\alpha_{1}}$

$$
\mathrm{W}_{\mathrm{t}}=\frac{\alpha_{1} \mathrm{U}_{2 \mathrm{t}}-\alpha_{1} \mathrm{U}_{1 \mathrm{t}}}{\beta_{1}-\alpha_{1}}
$$

From the six reduced form equations, $\left(\Pi_{0}, \Pi_{1}, \Pi_{2}, \Pi_{3}, \Pi_{4}\right.$ and $\left.\prod_{5}\right)$ six $\quad$ estimators $\left(\beta_{o}, \beta_{1}, \beta_{2}, \alpha_{o}, \alpha_{1}\right.$ and $\left.\alpha_{2}\right)$ can be indirectly estimated.

\section{RESULTS}

The empirical findings consist of two parts: descriptive statistics findings and inferential statistics findings.

Descriptive statistics results: Out of the 816 questionnaires sent out through the enumerators, 596 of them were completed. About 596 was therefore the sample size. 220 of the questionnaires were returned by the Enumerators uncompleted. The reason being that in the course of the interview between the Enumerators and some respondents, the Enumerators discovered that such respondents could not be included in the study because they did not use fertilizers during the study period. The mean value of the response rate in the three zones was $73 \%$. The questionnaire taken to Agricultural Input Supply Company (AISC), Akure, National Fertilizer Company of Nigeria (NAFCON), Fertilizer Procurement and Distribution Department (FPDD) Abuja now Federal Fertilizer Department (FFD), Abuja and ADP, Akure by the researchers were completed and promptly returned to the researchers. So, the response rate of these organizations was $100 \%$.

Fertilizer usage among the 596 farmers interviewed in the zones was $100 \%$. About $77.89 \%$ of the farmers interviewed reported receiving their fertilizers through the ADP outposts. About $17.01 \%$ of the farmers received their fertilizers through AISC while about 5.10\% reported receiving their fertilizers through ADP headquarters. 


\section{J. Social Sci., 6 (3): 498-507, 2010}

Table 1: Fertilizer supply, Consumption (Demand) and average subsidy price of fertilizers in Ondo State (1976-1996)

\begin{tabular}{lcccc}
\hline (1) Year & $\begin{array}{l}\text { (2) Quantity of fertilizers } \\
\text { supplied ('000 metric tons) }\end{array}$ & $\begin{array}{l}\text { (3) Quantity of fertilizers } \\
\text { consumed ('000 metric tons) }\end{array}$ & $\begin{array}{l}\text { (4) GAP (surplus/deficit) } \\
\text { ('000 metric tons) }\end{array}$ & $\begin{array}{r}\text { (5) Price per 50 KG } \\
\text { bag of fertilizers (N) }\end{array}$ \\
\hline 1976 & 902 & 596 & 306 & 2.0 \\
1977 & 1043 & 750 & 293 & 2.0 \\
1978 & 1205 & 950 & 255 & 2.0 \\
1979 & 1393 & 1022 & 370 & 2.0 \\
1980 & 1610 & 1174 & 436 & 2.5 \\
1981 & 1861 & 2748 & -887 & 2.5 \\
1982 & 2149 & 2900 & -751 & 2.5 \\
1983 & 2484 & 3100 & -616 & 2.5 \\
1984 & 2871 & 3300 & -429 & 6.0 \\
1985 & 3318 & 3561 & -243 & 9.0 \\
1986 & 3835 & 3750 & 85 & 10.0 \\
1987 & 4432 & 3950 & 482 & 10.0 \\
1988 & 5122 & 4200 & 922 & 10.0 \\
1989 & 5920 & 4400 & 1520 & 15.0 \\
1990 & 6842 & 4600 & 2242 & 20.0 \\
1991 & 7908 & 4800 & 3108 & 40.0 \\
1992 & 9140 & 5100 & 4040 & 50.0 \\
1993 & 5880 & 5300 & 580 & 1311 \\
1994 & 6811 & 5500 & 4200 & 150.0 \\
1995 & 10000 & 5800 & 7285 & 155.0 \\
1996 & 13285 & 6000 & 160.0 &
\end{tabular}

Sources: Column (2): FPDD and AISC Data Files; Column (3): ADP Data Files; Column (4): Computed by authors; Column (5): Ayoola et al. (2002). Towards a fertilizer regulatory and quality assurance system for Nigeria: An inventorization of the fertilizer sector, Federal Fertilizer Department (FFD), Federal Ministry of Agriculture and Rural Development, Abuja, p. xxiv of table of content

One of the key issues addressed by the questionnaires was the issue of the availability of fertilizers to farmers. About $72.33 \%$ of the farmers reported not receiving their fertilizers in sufficient quantities in the three zones, while $27.67 \%$ of the farmers reported receiving their fertilizers in sufficient quantities. $66 \%$ of the farmers in the three zones reported not receiving their fertilizers at the time of need while $34 \%$ reported receiving their fertilizers at the time of need.

Table 1 shows that the excess of supply of fertilizers over demand or consumption was on the average about 1715 metric tons per year while the excess of demand over supply was on the average about 585 metric tons annually.

Inferential statistics results: This sub-section presents the regression results of NAFCON's output of fertilizers without subsidy, the effect of subsidy on NAFCON's output of fertilizers with subsidy, the effect of NAFCON'S fertilizer output without subsidy on the quantity and price of fertilizers in Ondo State, the effect of NAFCON's output of fertilizers with subsidy on the quantity and price of fertilizers in Ondo State.

The choice of double log functional form in all the regression models in Table 2 over all other functional forms was premised on the fact that double log functional forms yielded better estimates. All the regression models were treated for first order positive serial autocorrelation with the use of Cochrane-Orcutt iteration procedure.
Models (A) and (B) are OLS regressions to show the effect of subsidy introduced at the plant level in form of input price support on the production of fertilizers by NAFCON. First, in model (A), the index of production of fertilizers by NAFCON was regressed on input index without subsidy. Second, in model (B), the index of production of fertilizers by NAFCON was regressed on input index without subsidy and index of input usage induced by the introduction of a subsidy. The subsidy rate was a $50 \%$ across-the-board input price support. The justification for this was that this was the subsidy rate granted on fertilizer subsidy by the Federal Government of Nigeria during the period of observation of NAFCON's production process.

The models in Table 2 were generally well behaved in terms of the values of their $R^{2}$, D.W statistics and $t$ ratios. The estimator attached to the independent variable in model (A) shows that a $1 \%$ increase in the usage of inputs without subsidy caused output of fertilizers by NAFCON to increase by about $1.72 \%$. However, there are two estimators in model (B). They are: the estimator attached to input usage without subsidy independent variable and the estimator attached to input usage induced by subsidy independent variable. The estimator attached to input usage without subsidy independent variable shows that a $1 \%$ increase in the usage of inputs without subsidy caused output of fertilizer by NAFCON to increase by about $0.674 \%$ while the estimator attached to input usage induced by subsidy independent variable would cause output of fertilizer to increase by about $5.043 \%$ if it increases by $1 \%$. 
Table 2: Ordinary least squares and two-stage least squares regression results

\begin{tabular}{|c|c|c|c|c|c|c|c|c|c|}
\hline \multirow[b]{2}{*}{ Models } & \multirow[b]{2}{*}{$\begin{array}{l}\text { Dependent } \\
\text { variables }\end{array}$} & \multirow[b]{2}{*}{ Constants } & \multicolumn{2}{|c|}{ Independent variables } & \multirow[b]{2}{*}{$\log P_{m}$} & \multirow[b]{2}{*}{$\mathrm{N}$} & \multirow[b]{2}{*}{$\mathrm{R}^{2}$} & \multirow[b]{2}{*}{ DW } & \multirow[b]{2}{*}{$\begin{array}{l}\text { Instrument } \\
\text { variables }\end{array}$} \\
\hline & & & $\log \left[\frac{\sum \mathrm{q}_{\mathrm{n}} \mathrm{P}_{\mathrm{o}}}{\sum \mathrm{q}_{\mathrm{o}} \mathrm{p}_{\mathrm{o}}}\right]$ & $\log \left[\frac{\sum_{s} \mathrm{q}_{\mathrm{n}} \mathrm{P}_{\mathrm{o}}}{\sum \mathrm{q}_{\mathrm{o}} \mathrm{p}_{\mathrm{o}}}\right]$ & & & & & \\
\hline A & $\log \left[\frac{\sum \mathrm{Q}_{\mathrm{n}} \mathrm{P}_{\mathrm{o}}}{\sum \mathrm{Q}_{\mathrm{o}} \mathrm{p}_{\mathrm{o}}}\right]$ & & $\begin{array}{r}1.720 * \\
(-40.459)\end{array}$ & & & 40 & 0.922 & 2.051 & \\
\hline B & $\log \left[\frac{\sum \mathrm{Q}_{\mathrm{n}} \mathrm{P}_{\mathrm{o}}}{\sum \mathrm{Q}_{\mathrm{o}} \mathrm{p}_{\mathrm{o}}}\right]$ & & $\begin{array}{r}0.674^{*} \\
(-35.015)\end{array}$ & $\begin{array}{r}5.043^{*} \\
(-26.284)\end{array}$ & & 40 & 0.992 & 2.051 & \\
\hline \multirow[t]{2}{*}{$\mathrm{C}_{\mathrm{ii}}$} & $\log \mathrm{Q}_{\mathrm{fso}}$ & $\begin{array}{l}5.894^{*} \\
(-9.137)\end{array}$ & & & $\begin{array}{l}0.377^{*} \\
(-4.218)\end{array}$ & 21 & 0.921 & 2.042 & $\mathrm{P}_{\mathrm{m}-1,}, \mathrm{Q}_{\mathrm{fso}-1}$ \\
\hline & $\log \mathrm{Q}_{\mathrm{fdo}}$ & $\begin{array}{l}7.337 * \\
(-5.294) \\
\text { Equilibrium } \\
\text { value: } \\
Q=8.312\end{array}$ & & & $\begin{array}{l}0.152^{*} \\
-9.245 \\
\text { Equilibrium } \\
\text { value: } \\
\mathrm{P}_{\mathrm{m}}=6.413\end{array}$ & 21 & 0.899 & 2.056 & $\mathrm{I}, \mathrm{Q}_{\mathrm{fdo}-1}$ \\
\hline \multirow[t]{2}{*}{$\mathrm{D}_{\mathrm{ii}}$} & $\log \mathrm{Q}_{\mathrm{fsso}}$ & $\begin{array}{l}5.766^{*} \\
(-13.154)\end{array}$ & & & $\begin{array}{l}0.400^{*} \\
(-6.376)\end{array}$ & 21 & 0.929 & 2.036 & $\mathrm{P}_{\mathrm{m}-1}, \mathrm{Q}_{\mathrm{fso}-1}$ \\
\hline & $\log \mathrm{Q}_{\mathrm{fdo}}$ & $\begin{array}{l}7.337 * \\
(-5.294) \\
\text { Equilibrium } \\
\text { value: } \\
Q=8.300\end{array}$ & & & $\begin{array}{l}0.152^{*} \\
(-9.245) \\
\text { Equilibrium } \\
\text { value: } \\
\mathrm{P}_{\mathrm{m}}=6.335\end{array}$ & 21 & 0.899 & 2.056 & $\mathrm{I}, \mathrm{Q}_{\mathrm{fdo}-1}$ \\
\hline
\end{tabular}

Note: (i) *: Significant at 5\% level; (ii) $t$ ratios in parentheses; (iii) Computed by authors

Model $\left(\mathrm{C}_{\mathrm{ii}}\right)$ is a two-stage least squares regression of quantity of fertilizers supplied to Ondo State without subsidy and quantity adopted (demanded) of fertilizers in Ondo State on the price of fertilizers in Ondo State. It must be noted that the value of the intercept term in the supply equation is 5.894 . When the two equations are set equal to each other, the value of $P_{m}$ is 6.413 and the value of $\mathrm{Q}$ is 8.312 .

Model $\left(D_{i i}\right)$ is also a two stage least squares regression of quantity of fertilizers supplied to Ondo State with subsidy and quantity adopted (demanded) of fertilizers in Ondo State on the price of fertilizers in Ondo State. It must be noted that the value of the intercept term in the supply equation decreased to 5.766 due to the fact that the variable $\mathrm{Q}_{\text {fso }}$ was multiplied by a scalar $(\mathrm{s}=5.043 \%)$ which was what the empirical result in model (B) suggested i.e., the supply curve in model (A) was to shift to the right due to the input price support (subsidy). The demand equation remains the same and when the two equations are set equal to each other, $\mathrm{P}_{\mathrm{m}}$ is 6.335 and $\mathrm{Q}$ is 8.300 .

The empirical results show that due to the introduction of a subsidy into the production process of NAFCON, more fertilizers are produced which caused the market supply curve of fertilizers in Ondo State to shift to the right causing the price of fertilizers at equilibrium in Ondo State to reduce while the quantity of fertilizers remains relatively unchanged.

\section{DISCUSSION}

From the findings from this study, it has been shown that the majority of the farmers in Ondo State who used fertilizers did not get the subsidized substance in sufficient quantities and at the time of need. This was so despite the fact that evidence shows that the supply of fertilizers consistently surpassed adoption (demand) during the study period.

Figure 1 shows that except for about 5 years of the study period i.e., from 1981-1985; supply of fertilizers constantly surpassed adoption (demand).The reason may be due to the fact that in 1979, the Green Revolution Program was introduced. Under this program, farmers were encouraged to adopt fertilizers and this probably spurred an increase in the adoption of fertilizers by farmers in Ondo State in the several years that immediately followed the introduction of the program.

The excess of supply over demand during the study period, especially from 1986 was probably due to two reasons. First, with the introduction of SAP in 1986, the Federal Government of Nigeria reduced the subsidy rates of fertilizers. This, coupled with the fact that there was a substantial leakage in the fertilizer subsidy scheme may have depressed fertilizer consumption (adoption) by the farmers. Second, during the study period, there was some effort on the part of the Federal Government of Nigeria to increase domestic fertilizer production. 


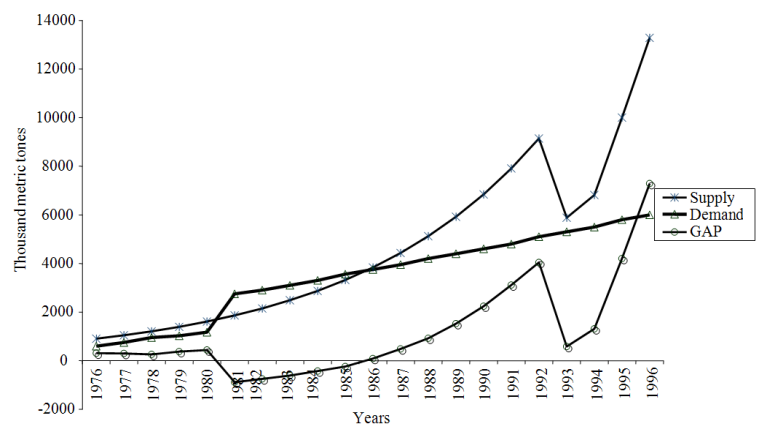

Fig. 1: Trend in fertilizers supply, adoption (demand) and supply/adoption (demand) GAP in Ondo State (1976-1996)

Hence, the National Fertilizer Company of Nigeria (NAFCON) was founded in 1988. The ensuing increase in domestic production may have widened the supply/demand gap.

Findings from this study have also shown that instead of allowing the farmers to enjoy subsidy when they take delivery of the subsidized substance at the ADP/AISC, the subsidy can be introduced at the plant level i.e., by subsidizing NAFCON's production of fertilizers. This will cause the supply curve of fertilizers to shift to the right due to the increased output induced by the subsidy. This will cause the market price of fertilizers to reduce in Ondo State while the quantities of fertilizers available in the market in Ondo State remain relatively unchanged as shown in Table 1. A calculation of the price elasticity of demand of fertilizers from the beginning to the end of the study period in Table 1 showed a coefficient of elasticity of 0.011 which was close to zero.

\section{CONCLUSION}

From the findings of this study, it can be concluded that during the study period, farmers in Ondo State adopted subsidized fertilizers. The fertilizers were distributed to the farmers through a long web of bureaucratic network. This network unwittingly encouraged the leakage or diversion of the fertilizers. This leakage or diversion prevented the fertilizers from getting to the farmers at the time of need and insufficient quantities. These violated the principle of inclusion i.e., the subsidy was not specific or not well targeted causing the intended beneficiaries to be excluded.

When the issue of an alternative way of administering the program was considered, it was discovered that introducing the subsidy via the production process of NAFCON would engender increased output of fertilizers (NPK and Urea). The increased output would cause the prices of the fertilizers to decrease in Ondo State. However, the quantities of fertilizers adopted would remain relatively unchanged because of the inelastic nature of the farmers' adoption or demand schedule for fertilizers in Ondo State.

The following are therefore recommended: the fertilizer prices in Nigeria should continue to be subsidized, but the modality of targeting must change such that the intended beneficiaries are not excluded.

The distribution logistics as it exists presently must be scrapped. The vast bureaucratic network through which fertilizers are distributed to the farmers must be totally by-passed. In its place, a system of distribution that is market-based must be instituted. This can be realized when the subsidy is introduced at the plant level. This will lead to increased output of fertilizer by NAFCON. A positive economic externality derivable from this is that fertilizers would be made available to farmers in Ondo State at reduced prices. However, the quantities of fertilizers available due to this reduction may not change because of the inelastic nature of farmers' fertilizers adoption or demand schedule in Ondo State. In order to make the schedule less inelastic, it is recommended that the Federal Government of Nigeria adopts a policy of an across-the-board subsidization of all fertilizer producing firms. This would encourage entrepreneurs to venture into fertilizer production thereby causing many firms of varying sizes to compete in the fertilizer industry i.e., creation of an industry that is monopolistically competitive. In return, all benefiting firms must submit themselves to the regulatory framework of the government in terms of internal management (productivity, due process in purchases) and quality control.

\section{REFERENCES}

Ayoola, G.B., V.O. Chude and A.H. Abdulsalam, 2002. Towards a fertilizer regulatory and quality assurance system for Nigeria. Federal Ministry of Agriculture and Rural Development.

David, C.C. and A.M. Balisacan, 1981. An analysis of fertilizer policies in the Philippines. Philippine J. Dev., 8: 21-37. http://ideas.repec.org/a/phd/pjdevt/jpd_1981_vol._ viii_nos._1\&2-b.html

Debra, K., 2001. Agricultural subsidies in sub-Saharan Africa: A reflection. IFDC Africa Division.

Gadzey, A., H. Thompson and O.A. Yeboah, 2005. Industrial subsidies in Alabama: Economic impact across counties. Southern Econ. Bus. J., 1: 3-7. http://www.auburn.edu/ thomph1/alindustrialpol.htm 
Goreux, L., 2004. Prejudice caused by industrialized countries subsidies to cotton sectors in Western and Central Africa. WTO.

Gujarati, D.N., 1987. Basic Econometrics. 1st Edn. McGraw-Hill, Auckland, ISBN: 10: 0070251827, pp: 462.

IFDC, 2003a. An action plan for developing agricultural input markets in Uganda. IFDC. http://pdf.usaid.gov/pdf_docs/PNACT958.pdf

IFDC, 2003b. Input subsidies and agricultural development: Issues and options for developing and transitional economies. IFDC. http://governmentpaid.com/input-subsidies-andagricultural-development-issues-and-options-fordeveloping-and-transitional-economies

IFDC, 2005. Developing Agricultural input markets in Nigeria (DAIMINA). http://pdf.usaid.gov/pdf_docs/PDACD463.pdf

Lingard, J., 2002. Agricultural subsidies and environmental change. Wiley.

Nagy, J.G. and O. Edun, 2002. Assessment of Nigerian government fertilizer policy and suggested alternative market-friendly policies, international fertilizer development centre. Muscle Shoals, Alabama.

Poonyth, D., A. Sarris, R. Sharma and S. Shui, 2004. Modeling the impact of cotton subsidies: The key analytical issues.

FAO. ftp://ftp.fao.org/docrep/fao/007/j2731e/j2731e00.pdf

Ranade, A. and G. Kapur, 2001. Sector report: Pharmaceutical industry. ABNAMRO.
Robin, S., R .Wolcott and C.E. Quintela, 2003. Perverse subsidies and the implications for biodiversity: A review of recent findings and the status of policy reforms. Proceeding of the 5th World Parks Congress: Sustainable Finance Stream, Sept. 2003, Durban, South Africa, pp: 1-11. http://www.conservationfinance.org/guide/WPC/W PC_documents/Overview_PanB_Wolcott_v2.pdf

Schumacher, K. and J. Sathaye, 1999. India's fertilizer industry: Productivity and energy efficiency. Environmental Energy Technologies Division. http://ies.lbl.gov/iespubs/41846.pdf

Shao, P.S., 1976. Statistics for Business and Economics. 13rd Edn., Macmillan Publishing Company, Columbus, Ohio, ISBN: 10; 067508640X, pp: 832.

Shepherd, B., 2005. The impact of US subsidies on the world cotton market: A reassessment. EconWPA. http://ideas.repec.org/p/wpa/wuwpit/0511012.html

Sumner, D.A., 2003. The impacts of US cotton subsidies on cotton prices and quantities: Simulation analysis for the WTO dispute. WTO. http://www.ncsu.edu/project/arepublication/Effects _US_Cotton_Subsidies.pdf

Zalla, T. and A.H.Y. Saad, 1998. Fertilizer production and marketing in Egypt: Baseline study. Ministry of Agriculture and Land Reclamation. http://www.abtassociates.com/reports/ES-IA02.pdf 